\title{
Crime Prevention Through Community Policing Interventions: Evidence from Harar City, Eastern Ethiopia
}

\author{
Melese Teferi Adugna'; Tesfaye Zeleke Italemahu² \\ ${ }^{1}$ Lecturer of Sociology, Haramaya University, Ethiopia; \\ ${ }^{2}$ Center for Environment and Development Studies, Addis Ababa University, Ethiopia \\ Corresponding Author: meleseqirqos@gmail.com
}

\begin{abstract}
In Ethiopia, community policing has been announced officially as a national program in 2005 E.C with the impetus to nullify crimes at lower tiers. There have been growing reports of prevailing crimes in Jenila district of Harar city. Accordingly, this study endeavors to scrutinize the practices of community policing and associated challenges in the study site. A mixed research deign was used to fetch out primary and secondary data sets. Hence, the participants' views were captured through questionnaires, key informant interviews and focused group discussions. The data were analyzed using descriptive statistics such as frequency, bar graph and percentages. The finding of the study revealed that a greater proportions of the respondents recognized that community policing practices had contributed in preventing crimes; burglary $94(27 \%)$ and robbery $77(22 \%)$ as most frequently recurring and reported types of crimes in the city. While community policing structures and concerned actors operate to smoothly run the programs, there were cropping up predicaments at the grass root levels. Limited awareness among the residents, inadequate financial resources and professionally ill-qualified human power were reported as major obstructions. In the face of increasing crimes, both in terms of intensity and types on the one hand, and intricate challenges to penetrate through on the other hand, the communities of residents aspire to dive deep with a sense of ownership and exploit the opportunities for intensifying the programs stated in community policing programs. Eventually, there was need to move in concerted manner to lessen the impacts of crimes in Jenila district of Harar city.
\end{abstract}

Keywords: community policing; crime prevention; eastern Ethiopia; harar city

\section{INTRODUCTION}

Community policing has been approached and practiced quite differently over time and within distinct contexts (Cossyleon, 2019). For Okeshola and Mudiare (2013), community policing entailed a paradigm shift that seeks to concentrate on constructive engagements with people who are beneficiaries of the police service and renegotiate the contract between the people and the police. Community policing falls on the premise that police alone cannot control crime and disorder and promote residents' quality of life (Fridell and Wycoff, 2004). Accordingly, community policing helps to prevent crime but it is not consistent in its practices (Jeremey and Cox, 2008).
While community policing initiatives have attained remarkable improvements in certain aspects, it does not seem to be the case for all communities in engaging in it because of the difficulty to get uniformity in crime prevention (Somerville,2014). As such, based on its definition of crime as an act prohibited and punishable by the law in its Penal Code (2006; Article 23 (1), the Ethiopian government had designed community policing as a strategy in preventing crime and urged the active involvement of all parties regardless of their cultural differences. Hence, the goal of this article was to analyze the practices of community policing in crime prevention along with underlying challenges in Jinela district of 
Harar city, Ethiopia.

Sherman and Eck (2006 cited in Alper, 2008) provide four major ways to make community policing work to prevent crime. The first is watch programs whereby residents keep their eyes on possible criminal activities in the community. The second is communitybased intelligence where information flows from the community to the police. The third is the police creating awareness among citizens regarding crime patterns and updated risks. And finally, there is police legitimacy i.e. the process of building public trust through collaborations and fostering law-abiding behavior among community members.

Contemporary crime prevention has generally embraced the value of partnerships and collaborative policy development and program delivery, in recognition that the causes of crime are wide and beyond the control of criminal justice agencies (Putt, 2010). This process brought institutions traditionally outside the criminal justice system such as family, education and community-based organizations to the drawing table for the development and implementation of crime prevention strategies (Brereton, 2000). The relevant agencies in crime prevention and control embraced their bigger role in ensuring peace and security to lay the basis for development, and this made community policing amicably tied to the process of creating inclusive, sustainable development. Through extending social networks in the public, community policing promotes social interaction and information dissemination that strengthen community relations and significant prevention and/or reduction of crime rates. This paradigm shift has significantly altered the role of the police. Instead of emphasizing on crime control, the police now works to partnership within the community in addressing problems that the community prioritizes (Alper, 2008). Through this manner, the police are more adept to prevent than control crime. Besides, as it harnesses collaborative community efforts with the community and different stakeholders, it promotes healthy social interaction that contributes significantly to reductions of crime rate in the community.

In the Ethiopian context, formal policing adheres to the broader national structures of ethnic federalism. As a result, there are Federal and Regional police forces for each of the nine National Regional States of Ethiopia. The Federal Police's jurisdiction lay in federally-administered cities of Addis Ababa and Dire Dawa, while providing support to the Regional police forces (Denney and Demelash, 2013). One of the most important questions about community policing is whether it is effective in addressing community crime and violence (Jeremey and Cox, 2008). In line with this notion, the practices of community policing in crime prevention need to be assessed and updated data is necessary for further understanding of the program in a given community. Furthermore, according to Frehiywot (2015) the general objective of community policing is to reduce crime and improve police-community relations. Therefore, one of the concern of the authors were to investigate the techniques employed by Jinela district community policing to deter crime before it occurs and underlying challenges observed in the course of actions.

For this study, crime prevention is defined as efforts to prevent crime or criminal offending in the first instance before the act has been committed (Brandon and David, 2012). Crime prevention activities categorized into three: such as primary, secondary, and tertiary. Primary prevention involves measures focused on improving the general well-being of individuals, secondary prevention focuses on intervening with children and youth who are at risk for becoming offenders or victims, and tertiary prevention involves measures directed toward those who have already been involved with crime. Furthermore, in the face of escalating crime rates, American law enforcement agencies have turned to the community for assistance (Lindsay and McGillis 1986, cited in Wilson and Susan, 1988). For instance, among types of crime, household burglary, in particular is an area of crime where collaboration between the community and the police is crucial. In fact, the householder is the only actor in a position to make a real difference to the burglary rate (Brandon and David, 2012). In Africa such as Nigeria, Tanzania, Uganda, South Africa, Kenya and many other countries of Sub- Saharan Africa, have long-established police forces with crime prevention mandates, among other duties (Van Der Spuy \& Röntsch, 2008 cited in Alliance). Consistent with these facts and considering the trends of crime rates in the study area, the researchers questioned how far community policing as a program is practicing in crime prevention and obstacles facing its implementation in Jinela district of Harar city, Ethiopia.

\section{THEORETICAL FRAMEWORK: SOCIAL NETWORK THEORY}

Social network analysis (SNA) focuses on ties among, for example, people, groups of people, organizations and countries (De Nooy and Mrvar, 2011). Arguments in favor of the use of SNA in prevention of crimes refer to its effectiveness due to the multitude of information that SNA may provide to the researcher, starting from such data as the hierarchy within the network, the impact of the 
network on an individual and its role as a risk factor of the commission of crime. Due to its universal character, SNA may be used in evidence-based policymaking in reference to public policies of combating various kinds of crime, for example terrorism, gang violence, drug dealing and human trafficking (Ptak, 2017). Much of this interest can be attributed to the appealing focus of social network analysis on relationships among social entities, and on the patterns and implications of these relationships.

From the view of social network analysis, the social environment can be expressed as patterns or regularities in relationships among interacting units. In addition to the use of relational concepts; actors and their actions are viewed as interdependent rather than independent, autonomous unit (Wasserman and Faust, 1999). Accordingly, for the successful implementations of community policing, there should be interdependence among interacting units of the society. On the contrary, if there is no network or connections between community policing and other partners, the result would be failure that could not achieve their goals. Information exchange, distributions of resources including human power between and within community policing and different stakeholders apparently imply the need for social network in Jinela district of Harar city. Furthermore, social network analysis avoids some of the limitations of existing approaches to mapping criminals' networks. It focuses on fluid interactions among individuals and determines social structures empirically, rather than relying on theoretical classifications thereby avoiding some of the pitfalls in traditional thinking about organized crime (Kriegler, 2014). That means in the modern state, controlling crime before it happens has become shaped by networks that integrate the public police with a host of other actors involved in the authorization and delivery of security services (Brewer, 2017).

Likewise, Social Network Analysis (SNA) helps us to understand criminal networks and victimization. For instance, knowing a person who associates with (whether she/he is a suspect, victim, or potential witness) can aid in predicting that person's future movements. It is well documented that crime and victimization are not randomly distributed across people or space. In addition, victims and offenders are often connected in multiple ways and play varying roles in criminal events (such as a victim or offender) and in daily social life (such as an acquaintance, family member, spouse/partner) (International Association of Crime Analysts report, 2018). Therefore, in practicing community policing as strategy in crime prevention, various stakeholders need to systematically create networks and share information there by combat crimes before it happens in the study site.

\section{METHODS \\ Study Site and Population}

The Harari Regional State is located in the Eastern part of Ethiopia; it is composed of the outer lowlands in its Eastern and Southern part. Harari Regional State has a total population of 183,391 where 99,368 urban and 84,023 rural, covering an area of 332 sq. km; the regional capital is Harar (ECSA, 2007). The Harar city has 19 districts among which Jinela district is found in the center of the city. Jinela district is well known in the city having many business centers, city bus station and high social interaction where the researchers gave much attention to conduct the study. The study populations were household heads living in the Jinela district of Harar city, community policing officers, experts from the criminal justice bureau and Harari Region's Supreme Court. Finally, the researchers conducted FGD with members of Jinela district community policing.

\section{Research Paradigm (Post-positivistic)}

This research assumes positivist research paradigm in order to address large sample size to generate knowledge using a set of scientific research practices mostly relies on quantitative approach where statistics is crucial in data analysis but to some extent supported by qualitative approach (Peter and Sinclair, 2013); (Charles, 2017) and (Riley, 2007). Hence, various stakeholders regarding the practices of community policing have been participated in which strong community involvements and networks positively influenced strategies behind crime prevention in the study site. The positivist paradigm also emphasizes genuine, real and factual happenings could be studied and observed scientifically and empirically and could as well be elucidated by way of lucid and rational investigation and analysis (Aliyu, et.al., 2014).

\section{Research Design}

Mixed research is considered as the corner stone of research within social science and enables to generate depth knowledge regarding the issue under investigation (Phillip, 2017). In this study, the researchers used mixed research design. The purpose was to collect quantitative and qualitative data simultaneously, but to have one form of data play a supportive role to the other form of data. The reason for collecting the secondary form of data is that it augments the primary form of data (Crasewell, 2012). 


\section{Sample Size Determination and Sampling Techniques}

For appropriate representation of the study population and to determine the sample size; the researchers assumed a $95 \%$ confidence level and $5 \%$ margin of error.

$$
n=\frac{N}{1+N e^{2}}
$$

Where $\mathrm{n}=$ Sample size

$\mathrm{N}=$ Total household in Jinela district of Harar city $\mathrm{e}=$ Margin of error

Accordingly,

$$
n=\frac{4030}{1+4030(0.05)^{2}}=350
$$

Therefore, the sample size of the study was 350 respondents from Jinela district. A simple random sample of 350 household heads from Jinela district was taken to gather the quantitative data using intervieweradministered questionnaire. On the other hand, to collect qualitative data, purposive sampling was employed to select key informant interviewees from Jinela district community policing officers, criminal justice experts, and Harari Region's Supreme Court. Focus group discussants were also carefully chosen using purposive sampling from police members of Jinela district to extract qualitative data.

\section{Data Collection Tools and Analysis}

The researchers used both qualitative and quantitative tools of data collection to ensure the reliability and validity of the data in the research findings. These include interviewer-administered questionnaire, key informant interview and FGD guides.

\section{Interviewer-administered Questionnaire}

With the interviewer-administered questionnaire, each respondent was asked the same sets of questions by the interviewer, in the same way, in order to eliminate possible bias. This method was chosen for its advantages of collecting detailed and complex data, the possibility to clarify misunderstandings and the opportunity for the interviewer to probe for additional information (Meadows, 2003). Accordingly, by taking sufficient time for data collection and using simple random sampling, the researchers gathered data from 350 household heads.

\section{Key Informant Interview}

Considering the importance of qualitative data, key informant interview was conducted with one participant from Jinela district community policing officer, two officers from Harar city police department, one expert from criminal justice bureau and one expert from Harari Region's Supreme Court (total of five key informants were successfully interviewed). Informants were selected using purposive sampling technique. During data collection, the researchers used the sound recorder to minimize omission of information with full willingness of the informants. The numbers of informants were determined during data collection on the basis of data saturation where the researchers came across in the field.

\section{Focus Group Discussion}

In order to collect sufficient qualitative data on the topic under investigation, three FGD were conducted (having six participants for the first FGD, seven for the second FGD and nine participants for the third FGD). As members were working in the same district and all of them were police, the researcher smoothly conducted the FGD. Data were collected using sound recorder and photographs with consent of discussants. During data

Table 1. Socio-demographic characteristics of the respondents

\begin{tabular}{|l|c|c|}
\hline Sex & Frequency & Percent \\
\hline Male & 216 & $61.7 \%$ \\
\hline Female & 134 & $38.3 \%$ \\
\hline Total & 350 & $100 \%$ \\
\hline Educational Status & Frequency & Percent \\
\hline Illiterate & 26 & $7.43 \%$ \\
Only Read and Write & 82 & $23.43 \%$ \\
Primary & 122 & $34.8 \%$ \\
Secondary & 60 & $17 \%$ \\
College Diploma & 29 & $8.3 \%$ \\
First Degree & 31 & $8.9 \%$ \\
Total & 350 & $100 \%$ \\
\hline Marital Status & Frequency & Percent \\
\hline Single & 60 & $17.1 \%$ \\
Married & 223 & $63.7 \%$ \\
Widowed & 31 & $8.9 \%$ \\
Divorced & 36 & $10.3 \%$ \\
Total & 350 & $100 \%$ \\
\hline Occupation & Frequency & Percent \\
\hline Merchants & 161 & $46 \%$ \\
Daily Laborers & 144 & $41.1 \%$ \\
Government Employees & 41 & $11.7 \%$ \\
NGOs & 4 & $1.14 \%$ \\
Total & 350 & $100 \%$ \\
\hline
\end{tabular}


collection, participants selected purposively when they were on short training in Jinela district of Harar city police department.

\section{Data Analysis Method}

Quantitative data were collected cautiously using coded questionnaires to reduce omissions and qualitative data were documented by means of video recorders and pictures. Quantitative data entered into a computer and cleaned for inconsistencies using SPSS version 21. Consequently, descriptive statistical methods of data analysis such as cross-tabulation, frequency, percentages, and bar-graphs were used. Regarding qualitative data, interpretations for quotations of informants using relevant descriptive statements of data analysis in line with the objectives of the study were employed.

\section{RESULTS AND DISCUSSIONS Socio-demographic Characteristics of the Respondents}

As shown in the below table 1, 216 (61.7\%) respondents were males and 134 (38.3\%) were females. Regarding educational level, $92.6 \%$ of the respondent can at least read and write; concerning their marital status, majority of the respondents $(223(63.7 \%))$ were married. Finally, $161(46 \%)$ and $144(41.1 \%)$ were economically active as merchants and daily laborers, respectively.

\section{Respondents' Perception on the Roles of Community Policing in Crime Prevention}

As shown in table 2, $210(60 \%)$ respondents believe that community policing has been working in crime prevention through several strategies to prevent crime. Of these, 57 (27.1\%) respondents said that community policing has been creating awareness to the community in the areas of crime prevention; 91 (43.3\%) respondents forwarded the presence of special attentions were given to vulnerable areas to crime like night clubs, while $62(29.5 \%)$ respondents claimed that youth had been recruited by the community policing and got knowledge about crime prevention in Jinela district. On the other hand, $140(40 \%)$ respondents informed that the role of community policing in crime prevention has not been noticeable.

However, there are scholars who argued that communities are often not equipped with the expertise or resources to tackle many of the crime-related problems that are of concern to them and thus the police must work with the community to implement community-based strategies. These activities are best addressed through establishing community-agency networks that would empower the community to act in the future (Cameron and Laycock, 2002).

Table 2. Role of Community Policing in Crime Prevention

\begin{tabular}{|c|c|c|c|}
\hline Questions & Responses & Frequency & Percent \\
\hline \multirow{3}{*}{$\begin{array}{l}\text { Do you } \\
\text { think that } \\
\text { community } \\
\text { policing has } \\
\text { been working } \\
\text { in crime } \\
\text { prevention } \\
\text { through } \\
\text { several } \\
\text { strategies? }\end{array}$} & Yes & 210 & $60 \%$ \\
\hline & No & 140 & $40 \%$ \\
\hline & Total & 350 & $100 \%$ \\
\hline \multicolumn{4}{|c|}{$\begin{array}{l}\text { Indicators of the crime prevention strategies in the } \\
\text { practices of community policing }\end{array}$} \\
\hline \multirow[t]{2}{*}{$\begin{array}{l}\text { If yes for } \\
\text { the above } \\
\text { question, what } \\
\text { do you specify } \\
\text { the crime } \\
\text { prevention } \\
\text { strategies? }\end{array}$} & $\begin{array}{l}\text { Creating } \\
\text { awareness } \\
\text { to the } \\
\text { community } \\
\text { on the } \\
\text { crime- } \\
\text { related } \\
\text { issues }\end{array}$ & $\begin{array}{l}\text { Given } \\
\text { especial } \\
\text { attention to } \\
\text { vulnerable } \\
\text { areas of } \\
\text { crime like } \\
\text { night clubs }\end{array}$ & $\begin{array}{l}\text { Recruiting } \\
\text { and train } \\
\text { youth } \\
\text { about } \\
\text { crime } \\
\text { prevention }\end{array}$ \\
\hline & $57(27.1 \%)$ & $91(43.3 \%)$ & $62(29.5 \%)$ \\
\hline
\end{tabular}

One of the FGD participants (sex: male, age: 29, educational level: Grade 10 completed) further added that:

In addition to the efforts made by the district community policing in crime prevention, the surrounding communities are solving minor conflicts such as insulting one another before the issue will transform into severe crime. The participants further reclaimed that insulting could easily lead to other forms of crimes of hurting one another. As a result, the cooperation of surrounding residents in creating peace through the principles of community policing among competing parties are very invaluable (January 2017, Venue: Jinela District Community Policing Office, Training Hall at Harar City).

The overall assertion is that elders or other individuals in the community were supporting the activities of community policing in crime prevention. Their interventions go to the levels of reducing the 
severity of the conflicting cases that occur in the context of the community. Other discussants in the FGD (sex: male, age: 33, educational level: diploma) who were also members of the district police stated that:

Following the attentions given on night clubs and business centers in complementation with the supports from youths to cooperate with community policing, there are remarkable achievements in crime prevention in this inner district. For example, the trend in the past was that offenders often create a problem on other persons and properties particularly around night clubs. Having recognized the prevailing situations, members of community policing and other concerned individuals have been drafting strategies to overcome and negotiating the disagreements between different individuals and parties. Through longer processes of negotiations several critical problems have been handled before creating severe damages (January 2017, Venue: Jinela District Community Policing Office, Training Hall at Harar City).

Hence, the above facts imply that through the supports from youths and other concerned individuals, community policing has continued to contribute to crime prevention in Jinela district. The overall reductions in crimes have also saved the community from the harms unnecessarily damaging individuals and their properties as well.

\section{Crimes and Concerns of Community Policing}

In a way, this assessment helps to identify the prevalent types of crimes in Jinela district of Harar city, from the respondents' perspective i.e. crime against property and person. Respondents were then requested to express their opinion about the types of crime categories mostly dealt by community policing in the district. The Figure 1 shows the result.

As shown in Figure 1, respondents identified the most prevalent type of crimes community policing dealt with in their district. For the majority of respondents, burglary $(94(27 \%))$ and robbery $77(22 \%)$ were the most frequently committed types of crime in the study area respectively. The city business mostly circulates in this district conveying large number of individuals for business activity. In sociology, higher levels of mobility entail increasing transactions and create breeding grounds for a number of crimes. Hence, from the data at hand, Jinela district hosts crimes against property as compared
Figure 1. Bar graph indicating types of crime (Source: Field Survey, January 2017)

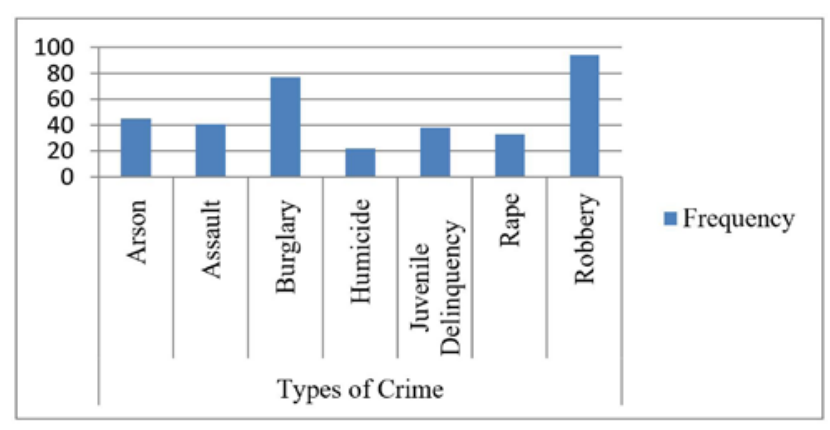

to against person mainly attributed to the operation of business in most of its geographical areas.

One of the key informants (sex: male, age: 42, educational level: degree) who was serving as an expert at Harari Region's Justice and Security Office forwarded that:

Following the district's introduction of community policing as a program to combat crimes, there has been a tendency towards reducing the number of crimes reported. For example, burglary was prevalent and challenging type of crime in the city prior to the commencement of community policing. However, following the implementation of community policing there is a significant change in terms of the number of crimes reported to us.

As mentioned above due to the existence and good practices of community policing, crimes such as burglary have been declining over time. There is possibility of uprooting such crimes if the district community policing continues to exert efforts to collaborate with the entire community and other stakeholders. The implication to be drawn here is that giving higher attentions to certain types of crime would lead to better achievements of security and peace in the community.

In an attempt to show the trends of crimes and efforts made by the district community policing, the researchers collected secondary data from Jinela district community policing of Harar city and cross-checked whether burglary and robbery are diminishing. For the convenience of this study, the researchers decided to the recent criminal record cases so as to show the progress in a while and precisely. The Figure 2 demonstrates burglary and robbery crime records for three consecutive years (from 2014 to 2016).

As clearly shown in Figure 2, there is a progress in crime prevention in the study area. For instance, between 
Figure 2. Burglary and Robbery crime records, 2014-2016

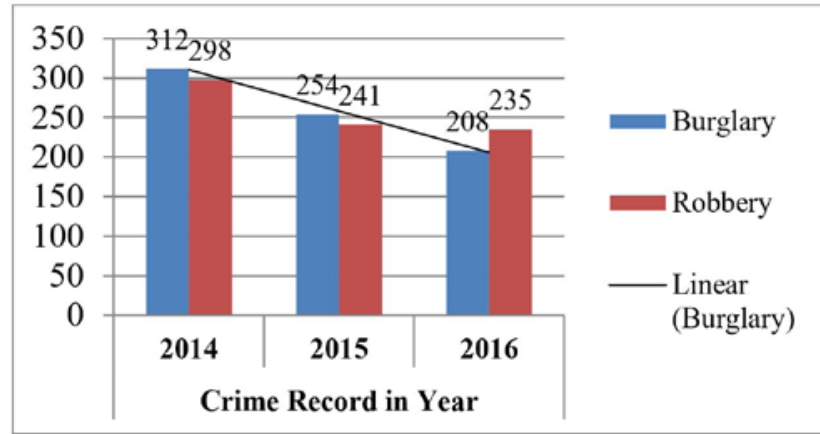

Source: Jinela district community policing annual crime report, January 2017: Harar City, Ethiopia)

2014 and 2016, there were $33.3 \%$ decline in burglary cases (from 312 to 208) and $21.1 \%$ decline in robbery cases (from 298 to 235). Even if the report indicates higher cases of burglary than robbery, the former's rate is declining at significantly higher rate than the formers. However, these fact entail that due to the efforts made by the district community policing, there is significant lessening of crime records and further indicates the practices of community policing is fruitful in reducing crimes in Jinela district of Harar city.

Furthermore, one of the FGD participants (sex: male, age: 28 , educational level: diploma) also added that:

From my observations, burglary and robbery have been highly prevalent during certain festival days such as religious celebration days. Following the introduction of community policing in the district, there were notable achievements in reducing such types of crime. This FGD discussant further reiterated that such types of crimes were often known as causes for assault and homicide. In fact, this requires concerted attention from district community policing (January 2017, Venue: Jinela District Community Policing Office, Training Hall at Harar City).

Several discussants and key informants stressed how criminals seek anonymity and favorable conditions to commit crimes, particularly during holidays, events, festivals, etc. where multitudes gather in public spaces. From this, they contend, the community as well as and members of community policing understood the dynamics of criminal activities and become alert. Furthermore, in thinking about community policing as a crime prevention strategy, Sherman and Eck (2006) cited neighborhood watch and community meetings as core strategies. Such strategies have been so effective in societies that live in the frameworks of imposed customary rules and social values through religious preaching and other cultural fabrics. The case at Jinela is not exceptional to such realities where communities share responsibilities and crimes could gradually reduce. Peace and stability are built not by external forces but need to evolve internally from community's own systems of living. Authors such as Wasserman and Faust (1999) advocated social support and group problem solving as mechanisms proposed to increase the network ties among actors. Hence, as crime prevention need social supports and cooperation of groups in solving the problems, the district community policing would better gear its activities with stakeholders through such frameworks on crime prevention. The increasing networks among stakeholders minimize the spaces for crimes in building the future of society, which is so safe for life and interactions.

\section{Major Challenges Hindering the Practices of Community Policing}

Under this sub-topic, the researchers have attempted to map out and report the main factors hindering the operational practices of community policing as a program in crime prevention in Jinela district of Harar city.

\section{Limited Awareness as a Crucial Factor in the Operation of Community Policing}

Awareness of a certain program including community policing helps to change the psychological attitudes of the residents and stakeholders in the courses of implementing the program. The respondents were approached to elicit their apprehensions. The below table demonstrates the respondents' opinion regarding their awareness of the practices of community policing as a program in crime prevention.

Table 3. Awareness related challenges of community policing practices

\begin{tabular}{|l|c|c|c|}
\hline Question & Response & Frequency & Percent \\
\hline Do you have & Yes & 112 & $32 \%$ \\
\cline { 2 - 4 } $\begin{array}{l}\text { awareness about } \\
\text { community policing } \\
\text { as a program in } \\
\text { crime prevention in } \\
\text { your district? }\end{array}$ & No & 238 & $68 \%$ \\
\cline { 2 - 4 } & & 350 & $100 \%$ \\
\hline
\end{tabular}

As presented in the above table, $112(32 \%)$ respondents reported that they have awareness about community policing as a program in crime prevention. 
Respondents said that they got awareness while attending public meetings, some respondents were members of community policing and awareness creations made by community policing experts including the advisory council of community policing. On the other hand, $238(68 \%)$ respondents do not have awareness about community policing. This figure indicates that majority of the respondents lack basic awareness about the practices of community policing. Accordingly, lack of awareness is the key challenging factor affecting the practices of community policing in Jinela district of Harar city. Lack of awareness distorts communities' cooperation with the police on security and prevention of criminal activities. Related with awareness issue, one of the participants (sex: male, age: 36 , educational level: diploma) in the FGD further claimed that:

Although there are some signs of progress in creating awareness to the community, still the community lacks a sense of ownership in accepting and practicing community policing in the district. Hence, community members need to develop the sense that community policing stands for them and belongs to them. Any problem of the community policing could be understood and interpreted as the problem of the community (January 2017, Venue: Jinela District Community Policing Office, Training Hall at Harar City).

Hence, the district community policing officer need to come up with a proposal and strategy in collaboration with other stakeholders to further instigate the awareness creation programs in the community. Partly, such activities of awareness creation could be handled through the universities, media, business community and sharing the experiences from other countries. It appears unlikely to succeed in the implementation of community policing programs without sufficient awareness in the community and every segment of the district.

\section{Financial Constraints as Distressing the Practices of Community policing}

The availability of financial resources affects a lot in the actual implementation of programs such as community policing and also the attainment of envisaged goals. The table below presents the respondents' opinion about financial constraints as the challenge impeding the practices of community policing in Jinela district of Harar city.

As shown in the table 4, $276(78.9 \%)$ respondents reported that there were financial constraints undermining
Table 4. Respondents' opinion about financial constraints on the operation of community policing

\begin{tabular}{|c|c|c|c|}
\hline Question & Response & Frequency & Percent \\
\hline \multirow{3}{*}{$\begin{array}{l}\text { In your } \\
\text { observations, is } \\
\text { there financial } \\
\text { constraints } \\
\text { undermining } \\
\text { the practices } \\
\text { of community } \\
\text { policing as a } \\
\text { program in crime } \\
\text { prevention? }\end{array}$} & Yes & 276 & $78.9 \%$ \\
\hline & No & 74 & $21.1 \%$ \\
\hline & Total & 350 & $100 \%$ \\
\hline
\end{tabular}

the practices of community policing as a program in crime prevention. Data collected from respondents indicated that Jinela district community policing could not frequently deliver awareness to the community, there is a shortage of stationeries, no incentives to the police, and less salary that imply financial shortages in the district. On the other hand, only $74(21.1 \%)$ respondents stated that there was no financial constraint challenging the practices of community policing. Hence, majority of the respondents admitted the presence of financial factors affecting the operational practices of community policing that negatively affecting the motivations of the experts in aggressively working out on crime prevention in the district.

In support of the aforementioned claims, one of the informants (sex: male, age: 38 , educational level: diploma) denoted that:

In other regions of the country, for example in Amhara and Oromia regional states there is an incentive and additional payments on their (community policing operators) salary. But in Harari region the improved structure of the salary has been delayed. Incentive payments were late and there is a financial constraint that is hindering the active participation of the community polices which hindered their performances in general. Additionally, problems related to numbers and qualities of services provided in the offices are in need of financial supports. Still, there is a lack of basic facilities including computers (some available computers in the offices are very old and not functional) and other imperative equipment and furniture (January 2017, Venue: Jinela District Community Policing Office: Harar City).

During the interview with Jinela district community 
policing officer, the researchers observed the internal structure of the office and captured that the office is below standard (it lacks furniture and computers). There is no separate room to sleep during the night shift of the officer and used the office for the same purpose.

Therefore, from the above facts, one can conclude that lack of financial support has been a burning issue in Jinela district of Harar city. To this end, in order to run effective community policing as a program in the district, business units, government bodies, the larger community and other stakeholders need to share and allot sufficient resources including financial supports. Strong sense of ownership would gradually emerge through such sharing of financial resources among actors in the community policing.

\section{Human Resources as Defying the Practices Community Policing}

Development that ignores human component remains unsuccessful. Developments in African countries including Ethiopia faced challenges of implementation and sustainability partly because of the shallow levels of attention offered to human development and capacity building program. Consequently, the views of the respondents were captured through the survey assessment and discussed over the next sub-paragraphs. The below table demonstrates respondents' observations about constraints related to lack of professionally trained and experienced human resources in the practices of community policing in Jinela district of Harar city.

Table 5. Human resources as a factor hindering the operation of community policing

\begin{tabular}{|l|c|c|c|}
\hline Question & Response & Frequency & Percent \\
\hline $\begin{array}{l}\text { Do you observe } \\
\text { a shortage of } \\
\text { human resources }\end{array}$ & Yes & 258 & $73.7 \%$ \\
\cline { 2 - 4 } $\begin{array}{l}\text { in community } \\
\text { policing as a } \\
\text { program in crime } \\
\text { prevention? }\end{array}$ & Total & 350 & $26.3 \%$ \\
\cline { 2 - 4 } & & 92 & $100 \%$ \\
\hline
\end{tabular}

As presented in table 5 above, 258(73.7\%) respondents reported that there were crucial problems related to human resources that have been manifested in different modalities. Such as: critical shortage of professionals in the fields of community policing, lack of skills and experiences in implementing community policing and low motivation to respond to the public safety and concerns that are bottlenecking crime prevention at the more adequate level in the district. This calls for the strategic interventions to overcome the human resource-related factors such as strategizing on training of proportionate human power, acquisition of reasonable training and skills as well as capacitating on duty community policing members to urgently respond to the concerns of the public.

One of the key informants (sex: male, age: 38 , educational level: diploma) who have been working in Jinela district community policing office recited cases of losing appropriate human power as follows:

There was a condition in which an experienced person that has been working in community policing had been called by top officials to run other key position. We missed such resourceful and experienced individuals easily. Consequently, we have been suffering from the burdens of training the newly recruited and appointed community polices. Normally, it takes them more time to execute the expected activities and accordingly adjust them to the system (January 2017, Venue: Jinela District Community Policing Office).

Similarly, as stated by a discussant (sex: male, age: 28 , educational level: Diploma) in FGD:

Due to shortage of human resources, from the existing community policing staffs, some members do not stay in the site for twenty-four hours (24 hours) and they have been feeling overburdened and not fully maintaining public safety (January 2017, Venue: Jinela District Community Policing Office, Training Hall at Harar City).

This extract could be understood that a higher number of community policing officers need to be deployed. In this respect, some findings also confirmed that when police system is understaffed, overworked and overstressed, they would eventually appear weak, stressed out, fatigued and sleepy on duty posts or in their patrol vehicles (Odinkalu, 2005). The finding in Jinela district of Harar city also proves the presence of analogous trends and practices on the ground.

\section{DISCUSSIONS}

In support of the finding of this research, prevailing knowledge has proved the effectiveness of strategically implementing community policing in crime prevention. Similarly, in Bangladesh, community policing helps to decrease crime as well as to ensure a crime-free area; the 
number of police stations and the police per thousand in Bangladesh is lower than any other country in the world so that community policing is needed as it demotivates criminal to attain crime and local people can solve their problems (Islam, 2018). For instance, Sherman and Eck (2002) were able to draw a number of conclusions regarding community policing as a crime prevention method. In this regard, community policing has improved the legitimacy of police operation which has been promising. Moreover, community policing initiatives have been found to reduce fear of crime and noted to proactively control crime (Brunson, 2015). Although community policing is effective in crime prevention, from the research finding it is witnessed that property crime is prevalent. According to (Lu and Wang, 2019), property crime may increase when potential offenders routinely travel from their own neighborhoods to more affluent environment. Similarly, the 2012 Commercial Victimization Survey of England and Wales showed that the vast majority of crimes against selected business sectors were property-related $(91 \%)$ experienced by the wholesale and retail sector (Office for National Statistics England and Wales, 2013). Hence, special focus need to be given to control crime against property so that the objectives of implementing community policing will be adressed in a moodest manner.

In line with the relevance of social network theory, finding indicated that neighborhoods and home watch network (in collaboration with police) are least vulnerable groups for crime which implicates the crucial role of network theory in practicing community policing as crime prevention strategy (Theresa, 2016). In principle, crime prevention was the major objective of community policing. Such an objective would be attained and realized through networks of stakeholders and other actors in the study site. The establishment of networks between stakeholders highly facilitates sharing of information and communication with focal bodies to timely report the progresses behind crime rates at various levels and pave ways to manage the expansions of crimes in a given community (Aromaa, 2010). This implies that community policing is effective by continuously strengthening its networks with various actors which contributes for combating crime.

It is observed that there are various challenges hinder the practices of community policing in the study site as well as evident in other countries. Study conducted in South Korea demonstrated that social awareness creates an appropriate climate, contributing to promote a safe town community as well as improve crime prevention (Dahee, 2019). However, study conducted in Bangladesh implicated that lack of awareness about the tactics of implementing community policing is a major challenge in controlling crime (Islam, 2018). It appears unlikely to succeed in the implementation of community policing programs without sufficient awareness in the community and every segment of the district.

Inadequate human resources have been another crucial obstacles confronting effective community policing practices in the district. For instance, Akuul (2011) stated that inadequate human power and poor deployment of personnel are the stumbling blocks to effective community policing in Nigeria. Moreover, Uma and Eboh (2013) argued that poor staff promotion, poor incentives, and weak operational strategies demoralize the police and weaken their functional capabilities. The research at hand also indicates unless timely and irreversible measures are taken, similar problems will occur in Harar city.

\section{CONCLUSION}

Based on the finding of this research, there were encouraging achievements in crime prevention on one side and identified underlying challenges are obstructing the practices of the program in Jinela district of Harar city on the other hand. The successes in crime preventions were attained through awareness creation, especial attention have been given to crime-prone areas including night clubs and empowering youths. There were also different types of crime that have been investigated and commonly reported in the district community policing. Among others, crime against property mainly robbery and burglary were highly prevalent. On the other hand, in Jinela district of Harar city, the researchers identified factors such as lack of awareness, financial restrictions, corruption and shortage of human resources that were obstructing the operations of community policing as a program in crime prevention.

\section{REFERENCES}

Akuul, T. (2011). The Role of the Nigerian Police Force in Maintaining Peace and Security in Nigeria. Journal of Social Science and Public Policy, 3.

Aliyu Ahmad Aliyu, M. U. B., Rozilah Kasim David Martin. (2014). Positivist and Non-Positivist Paradigm in Social Science Research: Conflicting Paradigms or Perfect Partners? Journal of Management and Sustainability, 4(3).

Alliance, C. B. (n.d). Crime Prevention Approaches in Africa. ELLA.

Aromaa, K. (2010). International Statistics on Crime and 
Criminal Justice. M. H. Stefan Harrendorf, Steven. Helsinki.

Atte, T. K. (2011). Assessing Factors that Affect the Implementation of Community Policing In Awassa, Federal Democratic Republic of Ethiopia. MA Thesis. University of South Africa.

Brandon C. Welsh, D. P. (2012). The Future of Crime Prevention: Developmental and Situational Strategies.

Brereton, D. (2000). Policing and crime prevention: Improving the product, in Chappell D and Wilson $\mathrm{P}$ (eds), Crime and the criminal justice system in Australia: 2000 and beyond. Sydney: Butterworths: 121-136

Brewer, R. (2017). Controlling crime through networks. ANU Press, the Australia National University, Canberra, Australia.

Brunson, A. A. B. A. R. K. (2015). The Police and Public Discourse on "Black-on-Black" Violence. New Perspectives in Policing.

Cameron, M. and Laycock, G. (2002). Crime Prevention in Australia. A. Graycar and P.Grabosky (eds) The Cambridge Handbook of Australian Criminology Melbourne: Cambridge University Press

Central Statistics Agency (2007). Population and Housing Census: Strategy and Implementation Plan, Addis Ababa, Ethiopia.

Charles Kivunja, A. B. K. (2017). Understanding and Applying Research Paradigms in Educational Contexts. International Journal of Higher Education 6(5), 26-41.

Clarke, M. F. (1998). Opportunity Makes the Thief: Practical theory for crime prevention. Research, Development and Statistics Directorate, Policing and Reducing Crime Unit. London: Crown Copyright.

Cerecina, M. (2012). Where is the Power in Community Policing? Program in Criminal Justice Policy and Management: Harvard Kennedy School.

Creswell, J. W. (2012). Educational Research: Planning, Conducting, and Evaluating Quantitative and Qualitative Research: University of Nebraska: Lincoln, USA

Cossyleon, J. (2019). Community Policing. The Wiley Blackwell Encyclopedia of Urban and Regional Studies._ResearchGate.

Cox, J. M. (2008). Community Policing and Crime: The Process and Impact of Problem-Solving in Oakland. Oakland: RAND Corporation.

Dahee Kim, S.-W. H. A. Y. J. (2019). Crime Prevention Eect of the Second Generation Crime Prevention through Environmental Design Project in South Korea: An Analysis. Social Sciences.

Denny and Demelash Kassaye (2013). Securing Communities for Development: Community Policing in Ethiopia's
Amhara National Regional State.

Faust, S. W. (1999). Social Network Analysis: Methods and Applications. Cambridge University Press.

Fisher-Stewart, G. (2007). Community Policing Explained: A Guide for Local Governments, U.S. Department of Justice.

Firehywot Mulat. (2015). An assessment of Challenges and Prospects of Implementation of Community Policing: the Case Study of Bole Sub-city. MP Thesis. Addis Ababa University, Addis Ababa, Ethiopia.

International Association of Crime Analysts. (2018). Social Network Analysis for Law Enforcement (White Paper 2018-02).

Islam, S. (2018). Community Policing (CP): Challenges on Preventing Crime and Human Security in Bangladesh. Review of Public Administrationand Management, 6(3).

Kriegler, A. (2014). Using social network analysis to profile organized crime. Institute for Security Studies.

Lu Wang, G. L. a. I. (2019). The Spatial and Social Patterning of Property and Violent Crime in Toronto Neighbourhoods: A Spatial-Quantitative Approach. International Journal of Geo-Information, 8(51).

Meadows, K. A. (2003). Questionnaire Design. British Journal of Community Nursing.

Mudiare, F. B. (2013). Community Policing in Nigeria: Challenges and Prospects. American International Journal of Contemporary Research.

Office for National Statistics England and Wales. (2013). Property Crime - Overview. London: Crown copyright.

Odinkalu, C. A. (2005). When did the police become your friend? Changing roles of civil society in promoting safety and security in Nigeria. E. E. O. Alemika\& I. C. Chukwuma (Eds.), Crime and policing in Nigeria: Challenges and options (pp. 28-44). Lagos: CLEEN Foundation

Peter Charles Sinclair Taylor, M. N. D. M. (2013). Educational research paradigms: From positivism to multiparadigmatic. Journal for Meaning-Centered Education, 1-14.

Phillip Bowen, R. R., Andrew Pilkington (2017). Mixed Methods-Theory and Practice. Sequential, Explanatory Approach. International Journal of Quantitative and Qualitative Research Methods, 5(2), 10-27.

PTAK, J. (2017). Social Network Analysis, Crime Prevention, and Human Rights.

Putt, J. (2010). Community policing in Australia. Australian Institute of Criminology.

Riley, D. (2007). The Paradox of Positivism. Social Science History, 31(1).

Scotland, J. (2012). Exploring the Philosophical Underpinnings of Research: Relating Ontology and 
Epistemology to the Methodology and Methods of the Scientific, Interpretive, and Critical Research Paradigms. English Language Teaching, Vol. 5.

Sherman, L. and Eck, J. (2002). Policing for Crime Prevention. L. Sherman, D. Farrington, B. Welsh \& D. MacKenzie (eds) Evidence-Based Crime Prevention London: Routledge

Somerville, P. (nd). Understanding Community Policing. University of Lincoln, $U K$.

Sozer, M. A. (2008). Assessing the Performance of Community Policing: the Effect of Community Policing Practices on Crime Rates. Dissertation. Indiana University of Pennsylvania.
Thanh, N. C. (2015). The Interconnection Between Interpretivist Paradigm and Qualitative Methods in Education. American Journal of Educational Science, 24-27.

Theresa, H. (2016). Modern Crime Prevention Strategy.

Uma, K. E., and Eboh, F. E. (2013). Corruption, economic development, and emerging markets: Evidence from Nigeria. Asian Journal of Management Sciences and Education, 3(3), 56-67.

Wilson, S. G. (1988). Crime Prevention: Theory and Action. Canberra : Australian Institute of Criminology.

Wycoff, L. F. (2004). Community Policing. Washington: Police Executive Research Forum, The Annie E. Casey Foundation. 